\title{
СЕМАНТИЧНА СТРУКТУРА НАЙМЕНУВАНЬ ЖИТЛОВИХ БУДІВЕЛЬ В АНГЛІЙСЬКІЙ, НІМЕЦЬКІЙ, ФРАНЦУЗЬКІЙ, УКРАЇНСЬКІЙ ТА РОСІЙСЬКІЙ МОВАХ
}

Просалова Я. В. Семантична структура найменувань житлових будівель в англійській, німецькій, французькій, українській та російській мовах.

У статті розглянуто іменники, що позначають житлові будівлі в п’яти мовах: двох германських, двох слов'янських і одній романській. За допомогою компонентного методу здійснено аналіз семантики складових цієї лексико-семантичної групи, визначені дві інваріантні та одинадцять уточнювальних ознак, що по-різному реалізуються в кожній мові. З'ясовано, що серед уточнювальних ознак найпоширенішими у найменуваннях житлових будівель $є$ ознаки особи та особливостей конструкції.

Ключові слова: семантика, компонентний аналіз, інваріантна ознака, уточнювальна ознака, найменування житлової будівлі.

Просалова Я. В. Семантическая структура наименований жилищных зданий в английском, немецком, французком, украинском и русском языках.

В статье рассмотрены существительные, обозначающие жилищные строения в пяти разноструктурных языках: двух германских, двух славянских и одном романском. Анализ семантики составных этой лексико-семантической группы осуществлён с помощью компонентного метода. Определены два инвариантных и одинадцать дифференциальных признаков, по-разному представленных в каждом из языков. Установлено, что самыми распространенными признаками в названиях жилищных строений являются признаки лица и конструктивних особенностей.

Ключевые слова: семантика, компонентный анализ, инвариантный признак, дифференциальный признак, название жилищного строения.

Prosalova Ya. V. The semantic structure of the dwelling names in English, German, French, Ukrainian and Russian.

The paper focuses on the nouns with the meaning of a dwelling house in English, German, French, Ukrainian and Russian. The analysis of this lexico-semantic group is based on the componential method. Two invariant and eleven differential semes are determined in the paper. They have a mixed embodiment in different languages. The semes of a person and constructional peculiarities prevail.

Key words: semantics, componential analysis, invariant seme, differential seme, the name of a dwelling house. 
1. Стаття присвячена семантичному аналізу іменників лексикосемантичної групи житлових будівель в англійській, німецькій, французькій, українській і російській мовах. Наприклад: фр. alcazar, нім. Alkazar, англ. alcazar, poc. алькасар 'іспанський палац’; англ. barracks, нім. Baracke, фр. baraque, poc. барак, укр. барак 'житлова будівля тимчасового користування (солдатами, робітниками)'. Житлові будівлі були об’єктом чималої кількості досліджень, найбільша частина яких виконана в етнографічному та лінгвокультурологічному аспектах [див. 12; $20 ; 22 ; 23 ; 32 ; 34]$. Однак уся увага лінгвокультурологів та архітекторів сконцентрована на більш значних з архітектурного боку будовах [33; 37; 40; 42], примітивне житло мало кого цікавило.

Об’єктом цієї статті є найменування житлових будівель (далі - НЖБ) в англійській, німецькій, французькій, українській і російській мовах. Предмет дослідження - номінативний лексико-семантичний варіант (ЛСВ) НЖБ у зазначених мовах. Матеріал для спостережень складають 472 НЖБ. Із них лексико-семантична група (далі ЛСГ) НЖБ в англійській мові представлена 81 лексемою (98 ЛСВ), у німецькій - 108 лексемами (114 ЛСВ), французькій - 75 (100 ЛСВ), українській - 92 (103 ЛСВ), російській -116 (122 ЛСВ).

Актуальність статті зумовлена необхідністю детальної розробки семантичного аспекту номінативних одиниць на прикладі окремих ЛСГ. Мета роботи полягає в дослідженні семантики НЖБ на матеріалі п'ятьох мов i передбачає розв'язання таких завдань: виокремлення спільних інтегральних ознак НЖБ; визначення видів диференційних ознак; 3'ясування домінантних ознак у кожній із мов; встановлення релевантних ознак у семантиці найменувань житлових будівель.

2. Семантика лексем, що позначають певні сфери дійсності, виявляє специфіку національного мислення, психологічної перцепції навколишнього середовища. Особливості сприйняття світу носіями певної мови визначаються насамперед завдяки таким семантичним сферам, що пов'язані 3 повсякденним життям, зокрема будівельною лексикою $[14$, с. 5].

Семантичний аналіз НЖБ здійснюється за традиційним підходом, який передбачає поділ логіко-предметного змісту лексем на окремі значення. Доцільність використання поняття 'лексико-семантичний варіант' замість 'різні значення' обгрунтовується у праці М.Ф. Алефіренка [1, с. 199]. Змістова структура полісемічного слова складається із сукупності ЛСВ, що мають ієрархічну організацію. На вершині цієї ієрархії знаходиться прямий номінативний ЛСВ, що $\epsilon$ категоріальним (інваріантним), йому протиставляються похідні (переносні) значення полісемічного слова [17, с. 115].

Компонентний аналіз грунтується на ідеї розкладення всього словникового складу мови на найменші елементи [24, с. 44; 39, с. 48]. Так, наприклад, В. Гуденаф здійснює компонентний аналіз термінів 
спорідненості, застосовуючи семантичну опозицію, в основі якої - певні семантичні ознаки, при цьому кожний смисловий компонент позначається літерою, а потім ці літери складаються. Сума літер має становити значення певного терміну [див. 31]). Недоліком компонентного аналізу $\epsilon$ суб'єктивність вибору дослідником ознак для розмежування [10], нечіткість критеріїв його проведення.

За компонентним аналізом значення досліджуваних НЖБ були розкладені на ЛСВ (семеми), а потім на семи. Сему вважають найменшою змістовою одиницею. За ієрархією сем В. Г. Гака [5, с. 151], у смисловій структурі НЖБ виокремлюється насамперед архісема (наприклад, англ. chateau - 'будівля, замок') і сема видового значення, а саме описова (англ. chateau - 'сільський будинок, особливо у Франції). Другий вид семи у класифікації В. Г. Гака - відносна [6, с. 248]. Виділені дослідником семи не зручні для опису семантики НЖБ. За іншим підходом до сем розрізняють інтегральні, тобто інваріантні, та диференційні (розпізнавальні) ознаки [39, с. 75, 114].

Заслуговує на увагу схема цілісної семантичної структури іменників ЛСГ назв споруд і знарядь праці, запропонована О. О. Погрібною, і понять семантичної домінанти i факультативних сем або факультативних компонентів, подібних за суттю до інваріантної та розпізнавальної сем відповідно [19, с. 85]. Але формула тлумачення лексем зазначених ЛСГ, виведена дослідницею, не придатна до аналізу НБ тому, що пропонується різний за характером і кількістю набір розпізнавальних ознак у НЖБ і НСБ.

В.А. Кусаковська при аналізі архітектурної лексики англійської мови спільні ознаки значень позначає двома термінами - інваріантною та домінантною ознаками, що доповнюються низкою уточнювальних [11]. Спільну для НЖБ ознаку значення назвемо інваріантною. Диференційні, розпізнавальні ознаки НБ позначатимуться як уточнювальні, що повною мірою відображає специфіку ЛСГ НЖБ.

3. Інваріантні ознаки значення. Матеріал дослідження при визначенні інваріантних та уточнювальних ознак у семантиці НБ обмежувався розглядом основного прямого значення, тобто ЛСВ, що $є$ вершиною ієрархічно організованої семантичної структури НБ. Спільною для НБ ознакою прямого значення $є$ сема «будівля», на основі якої здійснювався відбір матеріалу для дослідження. Слід зазначити, що кількість ЛСВ із цією семою більша за кількість досліджуваних слів, що мають ці ЛСВ. Наприклад, серед українських НЖБ кількість слів (W) - 92, a розглянутих ЛСВ - 103; у НЖБ російської мови ця різниця майже не помітна: poc. $\mathrm{W}-116$, ЛСВ -122 .

У зв’язку з тим, що аналізується ЛСГ житлових будівель, логічним є визначення такої інваріантної ознаки, як функціональне призначення. У НЖБ інваріантною ознакою $\epsilon$ «призначення для житла, перебування». Проживання / перебування може суттєво різнитися за часовими ๑ Я. В. Просалова, 2011. 
параметрами і наявне (імпліцитно чи експліцитно) у всіх НЖБ. Тому логічним здається виділення ще однієї інваріантної ознаки НЖБ: постійність / тимчасовість проживання. У таблиці 1 наведена кількість інваріантних ознак ЛСВ НБ:

Таблицяя 1

Інваріантні ознаки НЖБ

\begin{tabular}{|c|c|c|c|c|}
\hline \multirow[t]{2}{*}{ № } & \multirow{2}{*}{$\begin{array}{c}\text { Типи ознак } \\
\text { Мови }\end{array}$} & \multirow{2}{*}{$\begin{array}{l}\text { Константна } \\
\text { інваріантна }\end{array}$} & \multicolumn{2}{|c|}{ Відмінна } \\
\hline & & & постійність & тимчасовість \\
\hline 1 & англ. & 98 & 70 & 28 \\
\hline 2 & нім. & 113 & 83 & 30 \\
\hline 3 & франц. & 100 & 82 & 18 \\
\hline 4 & укр. & 103 & 87 & 16 \\
\hline 5 & poc. & 122 & 105 & 17 \\
\hline & Разом & 536 & 427 & 109 \\
\hline
\end{tabular}

Константна інваріантна ознака НЖБ 'для проживання, перебування' наявна в усіх лексичних одиницях цієї ЛСГ. Кількість першої інваріантної ознаки збігається з загальною кількістю номінативних ЛСВ НЖБ. За даними таблиці 1 можна зробити висновок, що серед НЖБ переважають лексеми зі спільною семою тривалості проживання. В англійській і німецькій мовах дещо більше НЖБ тимчасового характеру. Загалом розподіл лексем між постійним і тимчасовим житлом в усіх мовах приблизно однаковий.

4. Диференційні ознаки значень $є$ показниками специфіки компонентів ЛСГ НЖБ, за ними можна визначити особливості культури або умов життя народу. Зіставне дослідження задля виявлення різних рис мов у семантичному плані є дуже корисним: воно дає ключ до розуміння структури i змісту того, що називаємо культурою, сприяє кращому засвоєнню іншомовної лексики [38, с. 279].

Зіставляючи будівельні терміни на матеріалі англійської та російської мов, А. М. Письмиченко стверджує, що на рівні семантики помітна як відповідність, так і невідповідність значень лексичних одиниць через загальне розходження обсягу і системи значень у російській та англійській мовах. Неподібність у семантичній структурі термінів він пояснює відмінностями диференційних ознак, які формують ці поняття [18, с. 70$]$.

Уточнювальні ознаки значення не просто доповнюють інваріантну сему: сукупність створює ті неповторні комбінації, для найменування яких i виникає необхідність у мові. Унаслідок аналізу 536 ЛСВ НЖБ було виокремлено такі уточнювальні ознаки: розмір, форма, матеріал, особливості конструкції, розташування, ознака істоти / неістоти та інші. Наприклад:

1) ознака розміру: англ. castle 'замок' - ознака «великий», hostel 'готель' - ознака 'невеликий', нім. Kate 'хижа' - ознака 'невеликий', 
фp. bastide 'замок’ - ознака 'невеликий', укр. чертог - ознака 'великий', рос. шалаш - ознака 'невеликий';

2) ознака форми: англ. tерее 'типі' - ознака 'конусоподібний', нім. Iglu ‘іглу' - ознака 'куполоподібний', англ. longhouse 'довгий вігвам' - ознака 'довгий', фp. pavillon' 'палатка' - ознака 'квадратний або круглий', укр. шатро - ознака 'куполоподібний', рос. чум - ознака 'конусоподібний';

3) ознака матеріалу: нім. Baracke 'барак' - ознака 'дерево', фр. paillote 'хижа' - ознака 'солома', фр. carbet 'хижа спільного проживання' - ознака 'гілля', укр. кам'яниця - ознака 'камінь', рос. изба - ознака 'дерево’;

4) ознака особливостей конструкції: англ. dugout 'землянка' - ознака 'наполовину викопана у землі', англ. tabernacle 'шатро, намет' - ознака 'легка переносна конструкція', нім. Chateau 'замок' - ознака 'багато башт', фp. hutte 'хижа' - ознака 'переносний, мобільний', укр. юрта - ознака 'переносний', рос. чум - ознака 'переносний';

5) ознака розташування: англ. summerhouse 'заміський дім' - ознака 'у саду, парку', нім. Belvedere 'бельведер' - ознака 'таке, що надає гарного краєвиду', фр. pavillon' 'палатка' - ознака 'у полі', укр. шале - ознака 'у горах', рос. эрмитаж- ознака 'віддалений';

6) ознака істоти / неістоти: англ. vicarage 'будинок священика' - ознака 'священик', нім. Jagdhaus 'мисливська хатка' - ознака 'мисливець', фp. sérail ${ }^{1}$ 'сераль' - ознака 'султан', укр. колиба - ознака 'чабан, лісоруб', рос. монастырь - ознака 'монах';

7) країна / народність: укр. лоу 'високий будинок' - ознака 'Китай', укр. мегарон - ознака 'Греція', фр. bungalow 'бунгало' - ознака 'Індія', укр. вежа', рос. вежа - ознака 'давні кочові племена на території Росії;

8) оцінка: укр. палач, англ. palace, нім. Palast, фp. palais, poc. dвореu ознака 'розкішний', укр. хижса, рос. лачуга, халабуда, англ. hovel, hut, нім. Hütte, Kate, фp. masure, cahute - ознака 'вбоге, бідне';

9) додаткові особливості: нім. Internat 'інтернат' - ознака 'навчання разом із проживанням', англ. houseboat, нім. Hausboot 'дім на воді' - ознака 'для подорожей', фp. auberge ‘турбаза, готель' - ознака 'можливість поїсти';

10) належність до культової сфери: нім. Mönchskloster 'чоловічий монастир' - ознака 'церковне житло', укр. абатство, рос. абатство, фp. moutier ‘монастир' - ознака 'церковне житло’.

Джерелом аналізу семантики НЖБ слугують одномовні словники [2; 7 ; $8 ; 15 ; 21 ; 23 ; 26-30 ; 35 ; 41]$. При визначенні кількості сем враховано всі ознаки номінативного ЛСВ, наведені у тлумачних слониках. Розподіл уточнювальних семантичних ознак серед НЖБ у мовах, що аналізуються, наведений у таблиці 2. Цифри в дужках позначають поширеність ознаки у НЖБ певної мови: 
Види уточнювальних ознак НЖБ англійської, німецької, французької, української та російської мов

\begin{tabular}{|c|c|c|c|c|c|c|}
\hline Ознака & Англ. & Him. & $\Phi p$. & Укр. & Poc. & Разом \\
\hline 1. poзмip & $27(1)$ & $16(4)$ & $14(4)$ & $16(4)$ & $30(4)$ & 103 \\
\hline 2. ознака особи & $23(2)$ & $31(1)$ & $32(\mathbf{1})$ & $26(1)$ & $30(4)$ & 142 \\
\hline 3. розташування & $20(4)$ & $24(2)$ & $16(3)$ & $17(3)$ & $15(8)$ & 92 \\
\hline 4. особливості конструкції & $19(5)$ & $23(3)$ & $19(2)$ & $26(1)$ & $36(2)$ & 123 \\
\hline 5. країна / народність & $19(5)$ & $13(5)$ & $10(7)$ & $21(2)$ & $57(1)$ & 120 \\
\hline 6. призначення & $22(3)$ & $25(2)$ & $6(9)$ & $9(7)$ & $19(6)$ & 81 \\
\hline 7. матеріал & $10(6)$ & $12(6)$ & $8(8)$ & $14(5)$ & $31(3)$ & 75 \\
\hline 8. оцінка / зовн. вигляд & $10(6)$ & $10(8)$ & $12(6)$ & $13(6)$ & $13(9)$ & 58 \\
\hline 9. додаткові особливості & $6(8)$ & $11(7)$ & $8(8)$ & $13(6)$ & $17(7)$ & 55 \\
\hline $\begin{array}{l}\text { 10. належність } \\
\text { до культової сфери }\end{array}$ & $9(7)$ & $8(9)$ & $13(5)$ & $8(8)$ & $5(10)$ & 43 \\
\hline 11. форма & $6(8)$ & $6(10)$ & $2(\mathbf{1 0})$ & $9(7)$ & $21(5)$ & 44 \\
\hline Усього в мові & 171 & 179 & 140 & 172 & 274 & 937 \\
\hline
\end{tabular}

Серед НЖБ англійської мови найбільшою кількістю представлені ознаки розміру (27), особи (23), призначення і розташування (22 і 20). Ознаки країна / народність і особливості конструкції зустрічаються значно рідше (19 разів). Найменш поширеними в англійських НЖБ $є$ ознаки належності до певної суспільної сфери й оцінки (по 9 і 10), додаткових особливостей (6), форми (6).

Аналогічно англійській, у німецькій мові найчисельнішими також $\epsilon$ ознаки особи (31), призначення (25) і розташування (24), особливостей конструкції (23). Найменш вираженими є ознаки належності до певної сфери (8) і форми (6). На відміну від англійської мови, ознака розміру в німецькій зустрічається не так часто (див. Таблицю 2).

У НЖБ французької мови часто зустрічаються ознаки особи (32), особливостей конструкції (19), розташування (16) i розміру (14). Найменше виявлено ознак спеціального призначення (6) і форми (2). Другорядне значення мають інформація про матеріал, особливості конструкції, оцінку і спеціальне призначення будов.

Уточнювальні ознаки особи й особливостей конструкції переважають в українській мові (26), дещо меншою мірою виявлена ознака країни / народності (21). Ознаки розташування і розміру в українських ЖБ зустрічаються досить часто (17 і 16 відповідно), що подібно до англійської та німецької мов. Несуттєво відрізняється за кількістю ознак матеріалу, оцінки / зовнішнього вигляду, додаткових особливостей (13). Однаково виявленими $є$ ознаки призначення і форми (по 9). В українській мові, як і в англійській та німецькій, найменш поширеними є ознаки належності до культової сфери, призначення і форми. 
Серед НЖБ російської мови переважає ознака країна / народність (57), також широко виявлена ознака особливостей конструкції (36). Спостерігається не набагато менша кількість таких ознак, як матеріал (31), особа і розмір (30), форма (21). Додаткові особливості, розташування, оцінка / зовнішній вигляд не є настільки вагомими, як у германських мовах. Належність до культової сфери є найменш вираженою (5).

Загалом розподіл ознак за групами в досліджуваних мовах не збігається. Кожна мова має свою ознаку, що виявляється найбільш поширеною. Найменш поширеними у п'яти мовах $\epsilon$ ознаки форми та культової приналежності. Як і слід було очікувати, найбільше подібностей виявлено в парах українська / російська та німецька / англійська мови. При цьому подібність між українською та російською мовами $є$ більш вираженою. Для ЛСГ НЖБ важливими є ознаки, що найчастіше трапляються в мовах дослідження. Це ознаки особи, країни й особливостей конструкції будівель. Менш значущими є розмір і розташування.

5. Інваріантні ознаки універсальні у досліджуваних мовах, але поєднання цих ознак має свої особливості у кожній мові. Неповторні комбінації смислових ознак (сем) створюють неповторні семантичні структури слів у різних мовах і мовну неподільність світу загалом [13, с. 34].

Комбінаторика сем у ЛО із подібною зовнішньою формою слова в різних мовах може бути різною за характером і ступенем, що призводить до розширення або звуження змісту, розвитку нових значень, появи міжмовних омонімів тощо. Це можуть бути такі семантичні варіації, що значно змінюють семантику слів, віддаляючи їх від первісно заданої ознаки. У генетично споріднених мовах виявляється більше спільного в семантиці. Пор. poc. изба 'дім, житло російського селянина', друс. істьба 'дім, лазня', болг. изба 'землянка, погріб', серб. изба 'погріб', слн. izba 'кімната', пол. izba 'кімната, палата' тощо. Неспоріднені мови також відображають подібні закономірності семантичних перетворень (пор. укр. та рос. барак 'місцеперебування в'язнів' та англ. barrack - 'казарма для військових').

Семантичні особливості НЖБ розкриваються в типах поєднань двох або більше уточнювальних ознак. Кількість ознак у лексемі пов'язана зі специфікою позначуваного об'єкта - денотата. Очевидно, більш спеціалізовані будівлі мають містити більшу кількість диференційних ознак у порівнянні з НЖБ загальних типів. Наприклад, нім. Almhütte 'хижа чабана на гірському (альпійському) пасовищі' має кілька ознак: по-перше, ознака розміру 'невелика хата', по-друге, ознака оцінки або зовнішнього вигляду 'убога хата', по-третє, ознака особи 'чабан'. До того ж у цій лексемі дві ознаки розташування: у горах та на пасовищі. Французька НЖБ bicoque 'халупа' має три семи, які характеризують цю будівлю за розміром, виглядом, зокрема це ознаки розміру - 'малий', оцінки - бідний, додаткові особливості - 'некомфортний'. 
Специфіка самої будівлі не пов'язана з кількістю ознак у лексемі, якою ця будівля називається. Це зумовлено тим, що немає прямої відповідності між внутрішньою формою слова (змістом) і сприйняттям об’єктів навколишнього світу носіями мови, тобто мовною картиною світу певного народу.

Невідповідність семантичного наповнення НЖБ тій інформації, яку представляє денотат, яскраво виявляється на прикладі кількох лексем. Українська колиба позначає житло чабанів і лісорубів, тобто в іï значенні виокремлюється ознака особи. У новому тлумачному словнику української мови значення цієї НЖБ розкрите частково, бо зазначена лише одна ознака. Цим денотативне значення за тлумаченням словника вичерпується. Якщо спиратися на словникову дефініцію, можна прийти до висновку, що колиба завжди є житловою будівлею чабана. 3 позиції логічного аналізу виявляється, що колиба, навпаки, не є житлом чабана у будь-якому місці: у селі вівчар, як і інші, живе у звичайній хаті, такій, як і хлібороб. Сутність цієї лексеми можна визначити завдяки екстралінгвістичним чинникам: етнографічні студії про житло розкривають іï семантичний обсяг. Колиба набула значного поширення як житлова будівля тимчасового користування в Західній України. На відміну від куреня, вона має чотири або й більше зрубних стін. Дах, як правило, будують за класичною двосхилою формою або конічною з багатокутною основою і покривають драницями чи корою $[20$, c. 88]. Обов'язковим атрибутом колиби завжди було вогнище у центрі (за димар правив отвір у верхівці даху). Усі ці додаткові ознаки, які конкретизують значення НЖБ, не були наведені у словнику. Отже, у таблиці 2 були зазначені лише зафіксовані у словниках ознаки, бо не весь семантичний обсяг НЖБ виявлений у лексикографічних джерелах. Але навіть такий обсяг проаналізованого матеріалу дозволяє зробити висновок про відмінності у сприйнятті НЖБ носіями англійської, німецької, української, російської та української мов, зокрема наданні більшої значущості окремим уточнювальним ознакам. Поєднання кількох уточнювальних ознак НЖБ є виявом національно-культурної специфіки. Тому в перспективі дослідження - складання семантичної сітки комбінацій уточнювальних ознак НЖБ із метою виявлення універсальних та унікальних рис у семантиці житлових будівель.

\section{Література}

1. Алефиренко Н. Ф. Теория языка. Вводный курс : [учебник] / Н. Ф. Алефиренко. - М. : Академия, 2004. -368 c.

2. Великий тлумачний словник сучасної української мови (ВТС СУМ) / Гол. ред. В. Т. Бусел, ред. колегія : В. Т. Бусел, М. Д. Василега-Дерибас, О. В. Дмитрієв, Г. В. Латник, Г. В. Степенко. - К. : Ірпінь : ВТФ Перун, 2005. - 1728 с.

3. Виноградов В. В. Основные типы лексических значений слова / В. В. Виноградов // Вопросы языкознания. - 1953. - № 5. - С. 3-29.

4. Гулыга Е. В. О компонентном анализе значимых единиц языка / Е. В. Гулыга, Е. И. Шендельс // Принципы и методы семантических исследований / Гл. ред. В. Н. Ярцева. - М. : Наука, 1976. - С. $291-314$.

5. Гак В. Г. К проблеме общих семантических законов / В. Г. Гак // Общее и романское языкознание / Ред. А. П. Евгеньева. - М. : МГУ, 1972. - С. 144-157. 
6. Гак В. Г. Языковые преобразования / Владимир Григорьевич Гак. - М. : Языки русской культуры, 1998. - 763 с.

7. Даль В. И. Большой толковый словарь русского языка / Владимир Иванович Даль. - М. : АСТ, 2010. $-815 \mathrm{c}$.

8. Ефремова Т. Ф. Большой современный толковый словарь русского язика : в 3 т. / Т. Ф. Ефремова. M. : АCT, 2006. - T. 1. - 1165 c.; T. 2. -1160 c.; T. 3. -973 c.

9. Комлев Н. Г. Компоненты содержательной структуры слова : [монографія] / Н. Г. Комлев. - М. : Изд-во Моск. ун-та, 1969. - 192 с.

10. Кузнецов А. М. От компонентного анализа к компонентному синтезу / А. М. Кузнецов. - М. : Наука, 1986. - 124 c.

11. Кусаковська В. А. Співвідношення віртуального та актуального значення слова в англійській субмові архітектури та містобудування (досвід інтерпретації даних частотного словника): автореф. дис. ... канд. філол. наук / Вікторія Анатоліївна Кусаковська. - Одеса, 1994. - 15 с.

12. Листова Н. М. Крестьянское жилище Германии, Австрии и Швейцарии в ХIX в. / Н. М. Листова // Типы сельского жилища в странах зарубежной Европы / Отв. ред. С. А. Токарев. - М. : Наука, 1968. C. 178-220.

13. Манакін В. М. Деякі питання контрастивної лексикології слов'янських мов / В. М. Манакін // Мовознавство. - 2003. - № 4. - С. 26-37.

14. Миронова Г. М. Мотивація термінів східнослов'янської народної архітектури в етнолінгвістичному висвітленні / Г. М. Миронова // Мовознавство. - 1991. - № 4. - С. 21-30.

15. Новий тлумачний словник української мови : у 4-х т. / В. Яременко, О. Сліпушко. - К. : Аконіт, 1999. - Т. 1. - 914 c.; Т. 2. -912 c.; Т. 3. - 928 с.; T. 4. -942 c.

16. Ожегов С. И. Толковый словарь русского языка / С. И. Ожегов, Н. Ю. Шведова. - [4-е изд.,доп.]. - М. : Ити технологии, 2003. - 944 с.

17. Ольшанский И. Г. Лексическая полисемия в системе языка и тексте: (на материале немецкого языка) : [монографія] / И. Г. Ольшанский, В. П. Скиба. - Кишинев : Штиинца, 1987. - 127 с.

18. Письмиченко А. М. До питання про контрастивний аналіз термінології (на матеріалі будівельних термінів англійської та російської мов) / А. М. Письмиченко // Мовознавство. - 1981. - № 6. - С. 69-71.

19. Погрібна О.О. Дослідження семантичної структури іменникових дефініцій у тлумачному словнику // Мовознавство. - 2003. - № 1. - С. 84-88.

20. Присяжнюк В. Еволюція назв народного житла / В. Присяжнюк // Народна творчість та етнографія. - 1979. - №1. - С. 87-88.

21. Український тлумачний словник будівельних термінів / О. М. Лівінський, М. О. Лівінський, О. А. Васильковський та ін. - К. : УАН, МП Леся, 2006. - 528 с.

22. Ушаков Н. В. Жилище русских крестьян Петербургской губернии конца XIX - начала XX в. / Н. В. Ушаков // Петербург и губерния: Ист.-этногр. исследования / Ред. Н. В. Юхнева. - Л. : Наука, 1989. - C. $140-153$.

23. Чеснов Я. В. Лекции по исторической этнологии / Я. В. Чеснов. - М. : Гардарика, 1998. - 400 с.

24. Bendix E. H. Componental Analysis of General Vocabulary / E. H. Bendix // International Journal of American Linguistics. - 1966. - Vol. 32. - № 2. - P. 1-119.

25. CNTR : Project Commision Nationale des Titres Restaurantю - [Електронний ресурс] / Режим доступу : http://www.cnrtl.fr.

26. Collins English dictionary / Sandra Anderson. - 9th ed. - HarperCollins Publishers, 2007. - 1872 p.

27. Das digitale Wörterbuch der deutschen Sprache des 20 Jahrhunderts [Електронний ресурс]: Project der BBA der Wissenschaften. - Berlin : Alexander Geyken Redaktion, 2006. - Режим доступу : http://www.dwds.de

28. Dornseif F. Der Deutsche Wortschatz nach Sachgruppen / F. Dornseif. - Wiesbaden, Berlin : Walter de Gruyter \& Co, 2000. - S. 465-466.

29. DUDEN Deutsches Universalwörterbuch / Hrsg. von der Dudenredaktion. - 5., überarb. Aufl. Mannheim; Leipzig; Wien; Zürich : Dudenverlag 2003. - 1816 S.

30. Fleming J. The penguin dictionary of architecture. - Harmondsworth : Penguin books, 1979. $-315 \mathrm{p}$.

31. Goodenough W. Componential Analysis and the Study of Meaning / Ward H. Goodenough. Language. - Vol. 32. - No. 1. - 1956. - P. 195-216.

32. Jenkins S. England's Thousand Best Houses / Simon Jenkins. - Penguin books, 2003. - 950p.

33. Kähler G. Ein Jahrhundert Bauten in Deutschland / G. Kähler. - Stuttgart - München : Deutsche Verlags-Anhalt, 2000. - 236 s.

34. Kees Dorst. Understanding design / Dorst Kees. - Gingko Press, 2007 - 239 p.

35. Larousse Dictionnaire du Francais Contemporain Illustre (French Edition) / by Larousse Staff. - French \& European Pubns, 2008. - 1088 p. 
36. Leisi E. Der Wortinhalt. Seine Struktur im Deutschen und Englischen / Ernst Leisi. - Heidelberg : Quelle \& Meyer, 1961. - 135 S.

37. Modern country: reinterpreting a classic style / Nancy E. Ingram, M. J. Van Deventer, Jenifer Jordan. Layton : Gibbs Smith, 2006. - 144 p.

38. Östman J. O. Discursive Pragmatics / Jan-Ola Östman, Per Ledin, Jef Verschueren. - Amsterdam : John Benjamins Publishing Company, 2011. - 250 p.

39. Polguère A. Lexicologie et sémantique lexicale: notions fondamentales / Alain Polguère. - Montréal : Presses de l'Univ. de Montréal, 2003. - 260 S.

40. Ryan J. French Home / Josephine Ryan, Hilary Robertson, Claire Richardson. - London : Ryland Peters \& Small, 2007. - 159 p.

41. The Oxford Dictionary of English / Ed. Catherine Soanes and Angus Stevenson. - Oxford : Oxford University Press, 2001. - 1083 p.

42. Wohnsiedlungen: Entwürfe, Typen, Erfahrungen aus Deutschland, Österreich und der Schweiz / T. Hafner, B. Wohn, K. Rebholz-Chaves. - Basel - Berlin -Boston: Birkhäuser Verlag, 1998. - 311 s.

Стаття надійшла до редакції 2.11.2011 р. 